\title{
Dynamics of fish assemblages on a continuous rocky reef and adjacent unconsolidated habitats at Fernando de Noronha Archipelago, tropical western Atlantic
}

\author{
Paulo R. Medeiros ${ }^{1,2}$, Ricardo S. Rosa ${ }^{1}$ and Ronaldo B. Francini-Filho ${ }^{3}$
}

In recent years, many studies investigated how density-dependent factors, such as shortages in microhabitat and food availability influence the structure of reef fish assemblages. Most of what is currently known, however, comes from comparisons of isolated patch reefs and from correlations between fish abundance and one or few microhabitat variables. In addition, most studies were done in the Caribbean and Indo-Pacific regions, whereas the South Atlantic region has been, to date, understudied. The present study evaluated spatial and temporal variations in reef fish abundance and species richness in a continuous rocky reef and adjacent unconsolidated habitats in a Southwestern Atlantic reef, using underwater techniques to assess both fish numbers and microhabitat variables (depth, rugosity, number of crevices and percent cover of live benthic organisms, bare rock, sand, and limestone). Higher species richness was observed at consolidated substratum stations on both sampling periods (May and October), but fish abundance did not show a significant spatial variation. Topographical complexity and percent cover of algae (except coralline algae) were amongst the most important determinants of species richness, and correlations between fish size and refuge crevice size were observed. The non-random patterns of spatial variation in species richness, and to a lesser extent, fish abundance, were related to differences in substratum characteristics and the inherent characteristics of fishes (i.e. habitat preferences) and not to geographical barriers restraining fish movement. This study highlights the importance of concomitantly assessing several microhabitat variables to determine their relative influence in reef fish assemblages.

Em anos recentes, vários estudos investigaram como os fatores dependentes da densidade, por exemplo, a diminuição na disponibilidade de microhabitats e alimento, influenciam a estrutura das assembleias de peixes. A maior parte do que é atualmente conhecida, no entanto, é oriunda de comparações de recifes isolados e de correlações entre abundância de peixes e uma ou poucas variáveis relacionadas ao microhabitat. Ainda, a maior parte dos estudos foi realizada nas regiões do Caribe e do Indo-Pacífico, enquanto a região do Atlântico Sul tem sido, até o momento, subestimada. O presente estudo avaliou as variações espaciais e temporais da abundância de peixes recifais e da riqueza de espécies em um recife rochoso contínuo e em habitats não-consolidados adjacentes em um recife do Atlântico Sudoeste, utilizando técnicas subaquáticas para avaliar tanto os valores dos peixes como as variáveis do microhabitat (profundidade, rugosidade, número de fendas e porcentagem de cobertura de organismos bênticos vivos, rocha nua, areia e cascalho). Uma maior riqueza de espécies foi observada nos pontos de substrato consolidado em ambos os períodos de amostragem (maio e outubro), mas a abundância de peixes não mostrou uma variação espacial significativa. A complexidade topográfica e a porcentagem de cobertura de alga (exceto alga coralinácea) foram as determinantes da riqueza de espécies e correlações entre tamanho dos peixes e tamanho das fendas de refúgio mais importantes observadas. Os padrões não-randômicos de variação espacial na riqueza de espécies e, em menor grau, abundância de peixes, relacionaram-se com diferenças nas características do substrato e as características inerentes dos peixes (i.e. preferências de habitat) e não a barreiras geográficas restringindo o movimento dos peixes. Este estudo destaca a importância de avaliar concomitantemente diversas variáveis de microhabitat para determinar suas influências relativas sobre as assembleias de peixes.

Key words: Complexity, Distribution, Reef fishes, Reef habitats, Sandy habitats.

\footnotetext{
${ }^{1}$ Universidade Federal da Paraíba, Centro de Ciências Exatas e da Natureza, Cidade Universitária, 58059-900 João Pessoa, PB, Brazil. rsrosa@dse.ufpb.br

${ }^{2}$ Universidade Estadual da Paraíba, Departamento de Biologia, Rua Baraúnas, Campus Universitário, 58429-500 Campina Grande, PB, Brazil.medeirospr@gmail.com

${ }^{3}$ Universidade Federal da Paraíba, Departamento de Engenharia e Meio Ambiente, Rua da Mangueira, $58297-000$ Rio Tinto, PB, Brazil. rofilho@yahoo.com
} 


\section{Introduction}

Reef fish assemblages are amongst the best examples of coexistence of multiple individuals within a relatively small and confined space (Choat \& Bellwood, 1991; Bellwood \& Wainwright, 2002). For these competitively structured assemblages, factors such as shortages in microhabitat and food availability play important structuring roles (e.g. Russel et al., 1974; Sale, 1980; Denny, 1994; Chabanet et al., 1997; Ferreira et al., 2001). As a general rule, reef fish species richness and abundance are most likely to increase at sites with complex bottom structures, albeit in the case of fish density this relationship may not be universal (Gratwicke \& Speight, 2005).

Several substratum variables may influence the structure of reef fish assemblages, including topographic complexity (Charbonnel et al., 2002), number and size of crevices (Ault \& Johnson, 1998; Roberts \& Ormond, 1987), proportion of live cover (Ohman \& Rajasuriya, 1998) and hard substratum (Mellin et al., 2006), as well as vertical relief of the substratum (Gratwicke \& Speight, 2005). However, most fish-habitat studies performed to date investigated only one or few of these variables, resulting in incomplete evaluations. Given the variations in the relative importance of each of these factors, studies concomitantly investigating several variables provide a more comprehensive approach, as acknowledged by Gratwicke \& Speight (2005).

The majority of studies focusing on the small-scale dynamics of reef fish assemblages used small and isolated patch reefs as sampling units (e.g. Sale, 1977; Talbot et al., 1978; Wellington \& Victor, 1985; Hixon, 1991), and only few studies have investigated barrier-free, continuous reefs (e.g. Ault \& Johnson, 1998; Nanami \& Nishihira, 2003). This gap was originally recognized by Ault \& Johnson (1998), who experimentally compared reef fish assemblages on both continuous and isolated patch reefs with varying degrees of connectivity, concluding that greater reef size and connectivity enhances the ability of sedentary species to select more favorable microhabitats. As pinpointed by these authors and, more recently, by Nanami \& Nishihira (2003), results obtained from isolated patch reefs may not always be extrapolated to fish assemblages on continuous areas. In other words, the factors responsible for the composition and distribution of fishes in continuous areas may be different from those operating on isolated areas. Thus, further investigations on this issue are still necessary.

Despite a recent increase in the number of scientific investigations carried out in the Southwestern Atlantic region in the last decade (e.g. Francini-Filho et al., 2000; Ferreira et al., 2001; Floeter et al., 2007; Medeiros et al., 2010a), most of present day knowledge on reef fish ecology is based on studies of the Caribbean and Indo-Pacific regions. Given the uniqueness of Southwestern Atlantic reefs, particularly regarding factors such as coral composition and morphology (Maida \& Ferreira, 1997; Castro, 2003), algae abundance (Medeiros et al., 2010b) and reef fish composition (Floeter \& Gasparini, 2000), general patterns observed in other regions may not be properly applied to the former, as recently observed by Medeiros et al. (2010b). Therefore, studies in this poorlyinvestigated region are strongly encouraged.

The present study aimed to determine the extent to which reef fish distribution can be attributed to differences in several microhabitat characteristics in a continuous rocky reef and adjacent unconsolidated habitats in the oceanic archipelago of Fernando de Noronha, tropical Southwestern Atlantic. Temporal dynamics were also investigated by evaluating fish-habitat relationships in different seasons. Specifically, three general null hypotheses were tested: 1) reef fish assemblages are randomly distributed on both consolidated and unconsolidated substrata, regardless of microhabitat characteristics, 2) reef fish assemblages do not vary over time, and 3 ) reef fish assemblages are not influenced by habitat complexity.

\section{Material and Methods}

\section{Study area}

The study was conducted at Porto de Santo Antônio beach (hereafter referred to as Porto beach), Fernando de Noronha Archipelago, tropical western south Atlantic $\left(32^{\circ} 25^{\prime} \mathrm{W} 03^{\circ} 51^{\prime} \mathrm{S}\right)$. The archipelago is a marine protected area located at about $340 \mathrm{~km}$ off the Brazilian coast (Fig. 1). The study area is a semi-enclosed bay protected from water motion in its northeastern sector by an artificial barrier of large, piled igneous rocks with somewhat clear, calm waters in most of the year. The substratum in Porto beach is typically a mosaic of connected rocky reefs interspersed with sandy substrata in a continuous, barrier-free habitat. Our investigations were conducted in May and October of 2008, encompassing high and low precipitation periods, respectively.

Sampling was carried out during daytime using free dives at 30 non-overlapping permanent stations (i.e. separated by at least $5 \mathrm{~m}$; mean distance among adjacent points \pm SE: $13.4 \pm 2.2$ m) (Fig. 1). Stations were selected semi-systematically following the constraints stated above, and coordinates were determined with a portable GPS (Garmin eTrex) prior to the beginning of the study. Permanent stations were chosen, in detriment of random ones, given that the former provide higher sensitivity to detect temporal variations, particularly within patchy habitats showing high spatial heterogeneity (Rogers et al., 1994). Permanent stations are also a requisite for calculating the temporal stability index (see below). Water visibility was always higher than $10 \mathrm{~m}$ during the study period and all sampling stations were located at depths below $4 \mathrm{~m}$. To investigate the influence of substrata on reef fish distribution and population dynamics we distinguished stations as CS (consolidated substratum; 15 stations with $>70 \%$ of the area covered by hard substratum) and US (unconsolidated substratum; 15 stations with $>70 \%$ of the area covered by sand).

\section{Sampling procedure}

Fish numbers were assessed using an underwater visual census (UVC) technique. At each station a diver (PRM) placed four marks to set the limits of a $4 \mathrm{~m}^{2}$ quadrate $(2 \times 2 \mathrm{~m})$ 


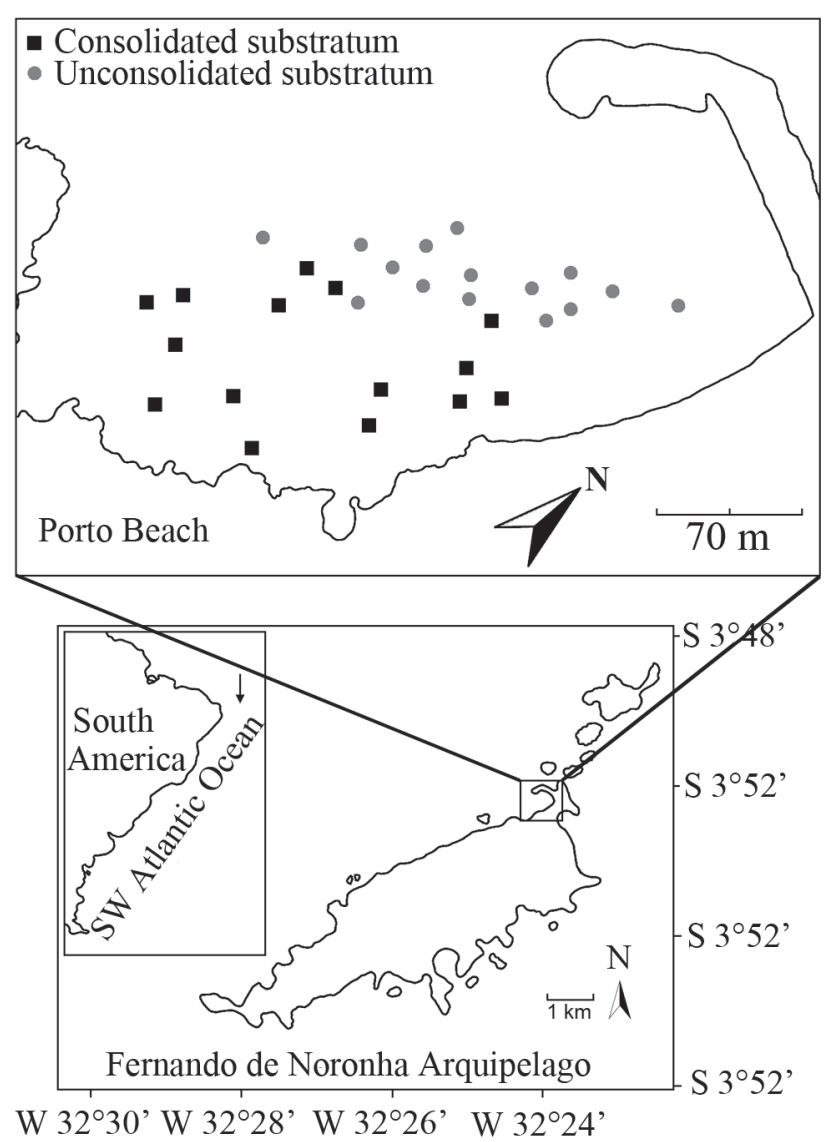

Fig. 1. Map of the Fernando de Noronha Archipelago showing the study area (Porto Beach) and permanent sampling stations.

and waited 2 minutes before beginning the census to allow fish to settle back from possible diver disturbances. Then, a 10 minutes period was spent counting all fishes located inside the quadrate with the observer remaining at a distance of 1-2 $\mathrm{m}$ from the perimeter to avoid any bias caused by his presence. An additional 2 minutes period was employed to actively search for hidden and cryptic fishes previously unrecorded over the substratum as a means to reduce the chance of underestimating cryptic species. A recent study conducted at Fernando de Noronha Archipelago testing precision and accuracy of different visual census methodologies indicates that a $4 \mathrm{~m}$ distance is suitable to detect both relatively small/sedentary and large/mobile fish (Minte-Vera et al., 2008).

During counting, juveniles were distinguished by coloration and, with the exception of small-bodied $(<10 \mathrm{~cm}$ total length, LT), cryptic species, individuals smaller than 5 $\mathrm{cm}$ were all considered juveniles (Ornellas \& Coutinho, 1998). Species identification followed Humann \& DeLoach (2002) and Lieske \& Myers (2001). Size of each individual was estimated to the nearest $\mathrm{cm}$. Extensive training with fish models was performed prior to sampling in order to minimize observer error (cf. Gust et al., 2001).
At each station structural complexity (rugosity and number of crevices), substratum height and percent cover of different benthic organisms were also assessed. These measurements of microhabitat characteristics were obtained at a $1 \mathrm{~m}^{2}$ quadrate $(1 \mathrm{x} 1 \mathrm{~m})$ in the centre of the $4 \mathrm{~m}^{2}$ quadrate in which fish counts were performed. Rugosity was assessed using the chain-link procedure (Luckhurst \& Luckhurst, 1978) by deploying a $1 \mathrm{~m}$ long chain at the centre of the quadrate, measuring the contour length and, subsequently, calculating the ratio of reef surface contour distance to the linear distance (i.e. $100 \mathrm{~cm}$ ). Number of crevices, and their estimated length, was assessed by recording the number of holes which could be used as temporary or permanent refuge for fishes (i.e. deeper than $2 \mathrm{~cm}$ and with a diameter $<50 \mathrm{~cm}$ ) located within the $1 \mathrm{~m}^{2}$ quadrate area. Substratum height was assessed by haphazardly dropping a led weight and measuring the vertical relief of benthic components at three points. This procedure was repeated three times at each $1 \mathrm{~m}^{2}$ quadrate, and the average value subsequently estimated for each sampling point. Substratum height ranged from few $\mathrm{cm}$ (e.g. corals and turf algae) to tenths of centimeters (e.g. macroalgae) and represents a measure of potential temporary refuge sites for small and mid-sized fishes. Percent cover was assessed with a chain following the procedures described by Porter (1972). We used the same chain described above and counted the links ( $5 \mathrm{~cm}$ size) located over each of seven benthic categories (encrusting coralline algae, macroalgae, turf algae, live coral, other organisms, bare rock, and sand plus limestone), chosen a priori based on pilot surveys and literature information (e.g. Rogers et al., 1994, Ferreira et al., 2001; Gratwicke \& Speight, 2005). We then counted the proportion of each substratum category relative to the total number of links in each chain.

\section{Data analysis}

Unless stated otherwise, analyses were restricted to species with relative abundance higher than $1 \%$ throughout the whole study. However, these rare species contributed to the variable 'fish species richness', and at each sample, they were quantified and included in the analyses. Firstly, we tested whether environmental and fish numbers differed as a function of the fixed factors substratum and sampling periods using a 2-way MANOVA(type III sum of squares) with $\log _{x+1}$ and square roottransformed data, respectively. We also tested the interaction term of these two factors. The test statistic Pillai trace was chosen given that it is more robust to violations of homogeneity of variances (Wilkinson et al., 1996). We also tested the effects of these fixed factors on species richness, abundance, and number of juveniles and adults using a series of two-way ANOVAs (type III sum of squares) with square root-transformed data. Tukey's HSD was used as a post-hoc test.

To determine the magnitude of assemblage dynamics (i.e. the magnitude of temporal changes in assemblage structure) at each habitat, two indexes proposed by Nanami \& Nishihira (2003) were employed. The first index (temporal fluctuation) was used to determine the extent to which assemblage composition fluctuated between the two periods, whereas 
the second index (temporal stability) was calculated for determining the degree of constancy in the assemblage between periods. We also measured the extent of temporal fluctuation in fish assemblage structure by calculating a coefficient of variation (CV) from each species and estimating the mean values of all CVs for each habitat (i.e. consolidated versus unconsolidated). High $\mathrm{CV}$ values suggest high temporal fluctuation in the assemblage. In addition, temporal stability was estimated by comparing pairwise measurements of fish density from the same permanent stations, but from the two different periods (e.g. site 1 May $v s$. site 1 October) via Pianka's index (Pianka, 1973), as follows:

$$
\alpha_{x}=\frac{\sum_{1 \mathrm{j}} \times \sum_{2 \mathrm{j}}}{\sum(1 \mathrm{j})^{2} \times \sum(2 \mathrm{j})^{2}}
$$

where: $\alpha_{x}=$ temporal stability of station $x ; \mathrm{U}_{1 \mathrm{j}}=$ number of individuals of the first sampling period and the $\mathrm{j}^{\text {th }}$ species; $\mathrm{U}_{2 \mathrm{j}}$ $=$ number of individuals of the second sampling period and the $\mathrm{j}^{\text {th }}$ species.

The above mentioned analyses were performed using the Ecosim software (Gotelli \& Graves, 1996) using data from all species simultaneously. This procedure resulted in one temporal stability value per station and 15 values per substratum type. Values ranged from 0 to 1 , with values closer to 1 indicating a higher degree of temporal stability (i.e. small variation in population size). To determine the significance of differences in population dynamics between substrata, unpaired Student's $t$ tests were used for both indexes.

To evaluate the influence of habitat characteristics on fish assemblage structure, a canonical correspondence analysis (CCA) was used. The downweighting of rare species option and the Monte Carlo randomization test (499 permutations under the reduced model) were used, this latter employed to determine the statistical significance of the correlations (ter Braak, 1986; ter Braak \& Verdonschat, 1995). To evaluate the relationship between size of crevices and fish size, additional correlations using Pearson's coefficient of correlation were made.

Some of the environmental variables were combined as an index to facilitate data interpretation. We weighted the variables with different scores (see Table 1) and summed their values for each sampling station, as follows: $\mathrm{IHC}=\mathrm{sR}+\mathrm{sL}+$ $\mathrm{sH}+\mathrm{sC}+\mathrm{sS}$, where: $\mathrm{IHC}=$ index of habitat complexity; $\mathrm{sR}=$ rugosity score; $\mathrm{sL}=\%$ cover of live organisms score; $\mathrm{sH}=\%$

Table 1. Microhabitat variables and arbitrary scores used to elaborate an index of habitat complexity (IHC) from results of underwater visual censuses.

\begin{tabular}{lccccc}
\hline Microhabitat variables & \multicolumn{5}{c}{ Resulting values /given scores } \\
\hline Rugosity (cm) & $0-10 / 1$ & $11-20 / 2$ & $21-30 / 3$ & $31-40 / 4$ & $>40 / 5$ \\
Live benthic cover (\%) & $0-19 / 1$ & $20-39 / 2$ & $40-59 / 3$ & $60-79 / 4$ & $80-100 / 5$ \\
Hard substratum (\%) & $0-19 / 1$ & $20-39 / 2$ & $40-59 / 3$ & $60-79 / 4$ & $80-100 / 5$ \\
Number of crevices & $0-7 / 1$ & $8-15 / 2$ & $16-23 / 3$ & $24-31 / 4$ & $>32 / 5$ \\
Substratum height (cm) & $0-10 / 1$ & $11-20 / 2$ & $21-30 / 3$ & $31-40 / 4$ & $>40 / 5$ \\
\hline
\end{tabular}

cover of hard substratum score (bare rock and encrusting coralline algae); $\mathrm{sC}=$ number of crevices score; $\mathrm{sS}=$ substratum height. IHC values were interpreted as follows: < 12 - low habitat complexity; $>12$ and $<20$ - intermediate habitat complexity and $>20$ - high habitat complexity.

To test the specific effect of habitat complexity on fish communities, species richness and fish abundance between the two substrata were compared using estimates of the IHC as a covariate in an ANCOVA design (type III sum of squares).

\section{Results}

Fish spatial distribution, population dynamics and the influence of substrate characteristics

Results of environmental characteristics are summarized in Table 2. There were significant spatial and temporal variations in microhabitat characteristics, with a nonsignificant interaction term, suggesting that spatial and temporal variability were independent from each other (Table $3)$. Rugosity, number of crevices and percent cover of turf algae, macroalgae, other organisms, and bare rock showed higher values at the consolidated substratum (CS) stations, whereas percent cover of encrusting coralline algae and sand plus limestone showed higher values at the unconsolidated substratum (US) stations (Tukey's HSD test; $\mathrm{p}<0.05$ ). At the CS stations, significant temporal fluctuations were detected for percent cover of encrusting coralline algae (higher values in May) and live coral (higher values in October), whereas at the US stations, rugosity, substratum height and percent cover of macroalgae were higher in May (Tukey's HSD test; $\mathrm{p}<0.05$ ).

During the study period, 3190 reef fish individuals of 26 species and 19 families were recorded (Table 4). The 2-way MANOVA revealed significant spatial and temporal variations in fish numbers, with a significant interaction term (Table 3). Seven species (A. saxatilis, C. fulva, C. ocellatus, O. trinitatis, $S$. axillare, and $S$. rocasensis) were significantly more abundant at the CS stations, and two species ( $H$. chrysargyreum and $H$. parra) were significantly more abundant at the US stations (Tukey's HSD test: $\mathrm{p}<0.05$ in all cases). At the CS stations, abundance of three species (Malacoctenus sp., O. trinitatis, and S. amplum) was higher in May, whereas at the US stations abundance of five species (A. saxatilis, A. chirurgus, H. radiatus, Malacoctenus sp., and S. frondosum) was higher in May. One species (S. amplum) showed higher values in October.

Fish species richness varied according to substratum type and sampling period, while fish abundance varied according to sampling period, with a non-significant interaction term in both cases (Tables 2 and 5). On both sampling periods fish species richness was higher at the CS stations (Tukey's HSD test; $\mathrm{p}<0.01$ ), whereas fish abundance did not differ significantly between substrata (Tukey's HSD test; $p>0.05$ ). There was no significant temporal variation in fish species richness at the CS stations, whereas higher richness values were observed in May at the US stations. Fish abundance 
Table 2. Mean values ( \pm SE) of microhabitat and fish variables from underwater visual census at 15 permanent consolidated substratum (CS) stations and 15 permanent unconsolidated substratum (US) stations from two sampling periods (May and October).

\begin{tabular}{|c|c|c|c|c|}
\hline \multirow[b]{2}{*}{ Microhabitat variables } & \multicolumn{2}{|c|}{ May } & \multicolumn{2}{|c|}{ October } \\
\hline & $\mathrm{CS}$ & US & $\mathrm{CS}$ & US \\
\hline Depth (m) & $1.9 \pm 0.2$ & $2.3 \pm 0.2$ & $1.6 \pm 0.1$ & $2.2 \pm 0.2$ \\
\hline Rugosity & $1.2 \pm 0.1$ & $1.1 \pm 0.1$ & $1.2 \pm 0.1$ & $1.1 \pm 0.1$ \\
\hline Number of crevices & $13.5 \pm 3.2$ & $4.5 \pm 0.8$ & $9.9 \pm 1.6$ & $2.8 \pm 0.6$ \\
\hline Substratum height $(\mathrm{cm})$ & $23.9 \pm 3.5$ & $21.5 \pm 2.8$ & $12.0 \pm 1.5$ & $5.1 \pm 1.2$ \\
\hline \multicolumn{5}{|l|}{$\%$ cover of } \\
\hline encrusting coralline algae & $1.7 \pm 0.8$ & $7.0 \pm 1.6$ & $0.0 \pm 0.0$ & $5.0 \pm 1.2$ \\
\hline Macroalgae & $46.5 \pm 6.5$ & $38.3 \pm 4.4$ & $44.0 \pm 3.9$ & $17.7 \pm 1.6$ \\
\hline turf algae & $26.0 \pm 6.9$ & $6.7 \pm 2.7$ & $29.7 \pm 5.2$ & $11.3 \pm 2.5$ \\
\hline live coral & $1.5 \pm 1.0$ & $1.7 \pm 0.8$ & $6.7 \pm 1.3$ & $4.7 \pm 1.7$ \\
\hline other organisms & $6.1 \pm 1.3$ & $3.3 \pm 2.2$ & $6.3 \pm 1.0$ & $1.7 \pm 1.1$ \\
\hline bare rock & $14.0 \pm 3.9$ & $2.0 \pm 1.1$ & $6.3 \pm 1.9$ & $1.0 \pm 0.7$ \\
\hline sand and limestone & $3.7 \pm 2.1$ & $41.0 \pm 5.8$ & $7.0 \pm 2.2$ & $58.7 \pm 4.0$ \\
\hline Index of habitat complexity & $12.9 \pm 0.5$ & $9.4 \pm 0.6$ & $11.5 \pm 0.4$ & $7.0 \pm 0.3$ \\
\hline \multicolumn{5}{|l|}{ Fish variables } \\
\hline Richness & $11.0 \pm 0.6$ & $7.3 \pm 0.5$ & $9.6 \pm 0.8$ & $5.0 \pm 0.5$ \\
\hline Abundance & $84.2 \pm 14.9$ & $48.9 \pm 8.9$ & $45.3 \pm 3.4$ & $34.2 \pm 7.0$ \\
\hline Juvenile abundance & $17.6 \pm 3.3$ & $10.1 \pm 1.7$ & $2.7 \pm 0.7$ & $1.2 \pm 0.4$ \\
\hline Adult abundance & $66.6 \pm 14.6$ & $38.9 \pm 7.9$ & $42.7 \pm 3.2$ & $33.0 \pm 7.0$ \\
\hline
\end{tabular}

showed the opposite pattern, with the CS stations showing higher values in May (Tukey's HSD test; $\mathrm{p}<0.05$ ) and no significant temporal variation at the US stations (Tukey's HSD test; $\mathrm{p}>0.05)$. Juvenile abundance varied solely temporally (Tukey's HSD test; $\mathrm{p}<0.001$ ), with no significant spatial or temporal variation recorded for adult abundance (Tukey's HSD test; $p>0.05$ ). The interaction term was significant for neither life stage (Tables 2 and 5). Post-hoc tests indicated that juvenile abundance was higher in May at both CS and US stations (Tukey's HSD test; $\mathrm{p}<0.05$ ).

Despite the low temporal variation observed for the majority of species, temporal fluctuation (CV) of fish assemblage was higher at the US stations $(\mathrm{t}=-2.06$; $\mathrm{df}=30 ; \mathrm{p}<0.05)$ and temporal stability (Pianka's index) was higher at the CS stations $(\mathrm{t}=2.22 ; \mathrm{df}=28 ; \mathrm{p}<0.05)$ (Fig. 2).

\section{Effects of habitat complexity on fish assemblages}

Canonical plotting of the first 2 axes is shown in Fig. 3. Cumulatively, these axes accounted for $49.5 \%$ of the relationship between microhabitat characteristics and fish abundance (test of significance of all axes: trace $=0.44$; Fratio $=1.48 ; p<0.01)$, with correlations between microhabitat and species of 0.84 (axis 1) and 0.71 (axis 2). The plotting shows

Table 3. Results of factorial MANOVAs testing the effects of substratum type (consolidated and unconsolidated), sampling month (May and October) and their interaction term on microhabitat variables (rugosity, number of crevices, substratum height and benthic cover) and fish abundances (rare species excluded). $n s$ : non-significant

\begin{tabular}{llcccc}
\hline & Effect & Pillai's trace & df & F & p \\
\hline Microhabitat & Substratum & 0.79 & 11 & 15.81 & $<0.001$ \\
variables & Month & 0.72 & 11 & 10.51 & $<0.001$ \\
& S x M & 0.26 & 11 & 1.46 & $n s$ \\
\hline Fish numbers & Substratum & 0.70 & 16 & 5.93 & $<0.001$ \\
& Month & 0.70 & 16 & 5.91 & $<0.001$ \\
& S x M & 0.48 & 16 & 2.39 & $<0.05$ \\
\hline
\end{tabular}

a clear segregation reflecting, primarily, the two substrata, particularly along the gradient of axis 1 . Species such as $C$. fulva, $H$. adscensionis, C. ocellatus, A. saxatilis, O. trinitatis, and $S$. rocasensis, which were positioned in the negative side of the plotting (bottom-left panel), strongly correlated with rugosity, number of crevices, and percent cover of most live organisms and bare rock. This zone clearly revealed the CS stations and its associated species, whereas the opposite, positive side of the plotting (upper-right panel), revealed the US stations. Here, percent cover of sand and limestone and coralline algae were the most important determinants, but species correlated poorly with these variables. Further, live coral and substratum height, intermediately located between zones, were somewhat poor determinants of species distribution. Many species were also positioned between zones, particularly wanderers (i.e. labrids, acanthurids, and scarids), but also sedentary and site-attached species (e.g. B. lunatus and Malacoctenus sp.); outlier species were represented almost exclusively by rare and/or schooling fishes.

Few correlations between size classes of fishes and crevices were detected, but these correlations were fairly robust, smaller individuals positively correlatin with small crevices and larger individuals correlating with larger crevices (Table 6).

With the effect of the IHC taken into consideration in the ANCOVA, substratum type had a significant influence on fish species richness, but not on fish abundance (Table 7). This was due to higher richness at the CS stations, which also showed higher IHC values.

\section{Discussion}

\section{Fish spatial distribution and the influence of substratum characteristics}

Microhabitat characteristics were strong predictors of reef fih distribution in a small-scale basis at Porto beach, Fernando de Noronha Archipelago. Given the continuous nature of the 
Table 4. Relative abundance (A\%) and mean values ( \pm SE) of fish abundance from 15 permanent consolidated substratum (CS) stations and 15 permanent unconsolidated substratum (US) stations from two sampling periods (May and October).

\begin{tabular}{|c|c|c|c|c|c|}
\hline \multirow[t]{2}{*}{ Family/Species } & \multirow[t]{2}{*}{$\mathrm{A} \%$} & \multicolumn{2}{|c|}{ May } & \multicolumn{2}{|c|}{ October } \\
\hline & & CS & US & CS & US \\
\hline \multicolumn{6}{|l|}{ Ophichthidae } \\
\hline Myrichthys ocellatus (Lesueur, 1825) & 0.1 & - & $0.1 \pm 0.1$ & - & - \\
\hline \multicolumn{6}{|l|}{ Holocentridae } \\
\hline Holocentrus adscensionis (Osbeck, 1765) & 0.4 & $0.4 \pm 0.3$ & $0.1 \pm 0.1$ & $0.3 \pm 0.2$ & - \\
\hline \multicolumn{6}{|l|}{ Aulostomidae } \\
\hline Aulostomus maculatus Valenciennes, 1841 & 0.2 & - & - & $0.3 \pm 0.1$ & $0.1 \pm 0.1$ \\
\hline \multicolumn{6}{|l|}{ Serranidae } \\
\hline Cephalopholis fulva (Linnaeus, 1758) & 1.3 & $1.8 \pm 0.5$ & $0.1 \pm 0.1$ & $0.7 \pm 0.3$ & $0.1 \pm 0.1$ \\
\hline \multicolumn{6}{|l|}{ Carangidae } \\
\hline Caranx latus Agassiz, 1831 & 0.2 & - & $0.1 \pm 0.1$ & $0.1 \pm 0.1$ & $0.1 \pm 0.1$ \\
\hline \multicolumn{6}{|l|}{ Haemulidae } \\
\hline Haemulon chrysargyreum Günther, 1859 & 9.2 & $4.4 \pm 3.3$ & $6.3 \pm 4.1$ & $0.1 \pm 0.1$ & $8.7 \pm 4.7$ \\
\hline Haemulon parra (Desmarest, 1823) & 5.3 & $1.7 \pm 1.0$ & $4.7 \pm 4.0$ & $2.7 \pm 1.3$ & $2.1 \pm 0.6$ \\
\hline Anisotremus surinamensis (Bloch, 1791) & 0.1 & $0.2 \pm 0.2$ & - & - & - \\
\hline \multicolumn{6}{|l|}{ Mullidae } \\
\hline Pseudupeneus maculatus (Bloch, 1793) & 1.0 & $0.7 \pm 0.3$ & $0.7 \pm 0.3$ & $0.5 \pm 0.1$ & $0.3 \pm 0.2$ \\
\hline \multicolumn{6}{|l|}{ Chaetodontidae } \\
\hline Chaetodon ocellatus Bloch, 1787 & 0.7 & $0.9 \pm 0.3$ & - & $0.5 \pm 0.3$ & $0.1 \pm 0.1$ \\
\hline \multicolumn{6}{|l|}{ Pomacanthidae } \\
\hline Pomacanthus paru (Bloch, 1787) & 0.1 & - & - & $0.1 \pm 0.1$ & - \\
\hline \multicolumn{6}{|l|}{ Pomacentridae $T$} \\
\hline Abudefduf saxatilis (Linnaeus, 1758) & 7.1 & $6.3 \pm 2.2$ & $1.1 \pm 0.6$ & $7.6 \pm 1.9$ & - \\
\hline Stegastes rocasensis (Emery, 1972) & 3.9 & $4.7 \pm 0.7$ & $0.2 \pm 0.1$ & $3.2 \pm 0.9$ & $0.3 \pm 0.2$ \\
\hline \multicolumn{6}{|l|}{ Labridae } \\
\hline Halichoeres radiatus (Linnaeus, 1758) & 5.0 & $3.2 \pm 0.6$ & $4.1 \pm 0.6$ & $2.3 \pm 0.4$ & $0.9 \pm 0.3$ \\
\hline Thalassoma noronhanum (Boulenger, 1890) & 34.2 & $25.1 \pm 4.0$ & $14.4 \pm 2.5$ & $16.2 \pm 2.0$ & $17.5 \pm 4.2$ \\
\hline \multicolumn{6}{|l|}{ Scaridae } \\
\hline Sparisoma amplum (Ranzani, 1841) & 1.4 & $1.8 \pm 0.5$ & $0.8 \pm 0.3$ & $0.3 \pm 0.2$ & - \\
\hline Sparisoma axillare (Steindachner, 1878) & 2.8 & $1.9 \pm 0.5$ & $0.5 \pm 0.2$ & $2.4 \pm 0.5$ & $1.1 \pm 0.4$ \\
\hline Sparisoma frondosum (Agassiz, 1831) & 1.5 & $0.6 \pm 0.2$ & $1.3 \pm 0.4$ & $1.1 \pm 0.4$ & $0.2 \pm 0.1$ \\
\hline \multicolumn{6}{|l|}{ Labrisomidae } \\
\hline Malacoctenus sp. & 8.6 & $8.1 \pm 2.2$ & $6.3 \pm 0.8$ & $2.9 \pm 0.6$ & $0.9 \pm 0.3$ \\
\hline \multicolumn{6}{|l|}{ Blenniidae } \\
\hline Ophioblennius trinitatis Miranda Ribeiro, 1919 & 2.4 & $4.1 \pm 1.2$ & $0.4 \pm 0.3$ & $0.5 \pm 0.2$ & - \\
\hline \multicolumn{6}{|l|}{ Gobiidae } \\
\hline Coryphopterus glaucofraenum Gill, 1863 & 0.5 & $1.1 \pm 0.9$ & - & - & - \\
\hline \multicolumn{6}{|l|}{ Acanthuridae } \\
\hline Acanthurus chirurgus (Bloch, 1787) & 10.6 & $12.7 \pm 8.1$ & $7.1 \pm 3.6$ & $2.1 \pm 0.7$ & $0.8 \pm 0.5$ \\
\hline Acanthurus coeruleus Bloch \& Schneider, 1801 & 2.5 & $3.0 \pm 2.5$ & $0.5 \pm 0.3$ & $1.2 \pm 1.0$ & $0.7 \pm 0.7$ \\
\hline \multicolumn{6}{|l|}{ Sphyraenidae } \\
\hline Sphyraena guachancho Cuvier, 1829 & 0.6 & $1.4 \pm 1.3$ & - & - & - \\
\hline \multicolumn{6}{|l|}{ Bothidae } \\
\hline Bothus lunatus (Linnaeus, 1758) & 0.2 & $0.1 \pm 0.1$ & - & $0.1 \pm 0.1$ & $0.1 \pm 0.1$ \\
\hline Ostraciidae & & & & & \\
\hline Lactophrys trigonus (Linnaeus, 1758) & 0.1 & - & $0.1 \pm 0.1$ & - & $0.1 \pm 0.1$ \\
\hline
\end{tabular}

rocky reef and the consequential lack of constraints to fish movement (Sale, 2004), the observed patterns strongly indicate fish preference for consolidated substrates. Alternatively, spatial variation may be related to selective predation on different microhabitats, with higher predation rates taking place at sites with less shelter due to lower substratum complexity. Although these spatial differences were more evident at the species richness level (i.e. fish composition), differences in the abundance of sedentary and site-attached species were also recorded.

The positive effect of consolidated substratum on species richness has been acknowledged before (e.g. Mellin et al., 2006). Our observations suggest, however, that the consolidated substratum will have a positive effect on species richness only at locations with high topographic complexity and diverse benthic cover. In this case, a hypothetical consolidated site with low architectural complexity and uncolonized by benthic organisms is, supposedly, just as attractive to reef fish as unconsolidated substata. Despite a higher number of individuals recorded in the consolidate substratum, a significant effect of substratum type on fish abundance was not detected in this study. This result is in accordance with several other studies which also showed no relationship between habitat complexity and fish abundance. Gratwicke \& Speight (2005), for example, showed that rugosity positively determines fish species richness, but not abundance, in a series of marine habitats. As opposed to species richness, fish abundance is dependent upon several factors other than those solely related to microhabitat characteristics, namely, recruitment, mortality, competition, 
Table 5. Results of factorial ANOVAs testing the effects of substratum type, sampling month and their interaction term on fish variables from 15 permanent consolidated substratum (CS) stations and 15 permanent unconsolidated substratum (US) stations. $n s$ : non-significant

\begin{tabular}{llcccc}
\hline Fish variables & Effect & $d f$ & MS & $F$ & $P$ \\
\hline Richness & Substratum & 1 & 256.27 & 50.37 & $<0.001$ \\
& Month & 1 & 52.27 & 10.27 & $<0.01$ \\
& S x M & 1 & 3.27 & 0.64 & $n s$ \\
& Residual & 56 & 5.09 & & \\
\hline Abundance & Substratum & 1 & 8073.60 & 5.96 & $n s$ \\
& Month & 1 & 10773.60 & 7.95 & $<0.01$ \\
& S x M & 1 & 2184.10 & 1.61 & $n s$ \\
& Residual & 56 & 1355.20 & & \\
\hline Juveniles & Substratum & 1 & 6.68 & 6.59 & $n s$ \\
& Month & 1 & 59.57 & 58.75 & $<0.001$ \\
& S x M & 1 & 1.04 & 1.02 & $n s$ \\
& Residual & 56 & 1.01 & & \\
\hline Adults & Substratum & 1 & 30.69 & 6.79 & $n s$ \\
& Month & 1 & 11.44 & 2.53 & $n s$ \\
& S x M & 1 & 1.56 & 0.34 & $n s$ \\
& Residual & 56 & 4.52 & & \\
\hline
\end{tabular}

and predation (Chabanet et al., 1997). Although these factors may also be important for species richness, they may influence the latter attribute in a lesser extent. It is clear that additional studies are still needed in order to better understand the influence of microhabitat characteristics on fish abundance and species richness.

The Noronha wrasse Thalassoma noronhanum was by far the most abundant and common species on both types of substrata (see Francini-Filho et al., 2000 and Minte-Vera et al., 2008 for similar results). Despite being nearly 20\% more abundant at the consolidated substratum stations, spatial differences were not significant. The latter result may be related to the versatility in feeding and habitat utilization patterns by this species (see Campos et al., 2006). The haemulids Haemulon chrysargyreum and $H$. parra were more abundant at the unconsolidated substratum stations. Sandy bottoms are amongst the preferred sites for these burrowing invertebrate pickers (Randall, 1967), what may explain their non-random distribution at Porto beach.

\section{Temporal dynamics in the structure of fish assemblages}

Microhabitat characteristics showed small temporal fluctuations. The most prominent difference was observed for substratum height (higher values recorded in May), particularly due to differences in macroalgae height (the most important determinant of substratum height at the study site). Although coral and rocky reefs usually show small temporal dynamics, temporal variations in the abundance of macroalgae are frequently detected (e.g. Costa Jr. et al., 2001; Lefévre \& Bellwood, 2010).

Similarly to microhabitat characteristics, the abundances of only four fish species showed significant differences between seasons. These differences are most likely related to inherent short-term population dynamics of each species (e.g. recruitment, mortality, and small scale migrations), and not as

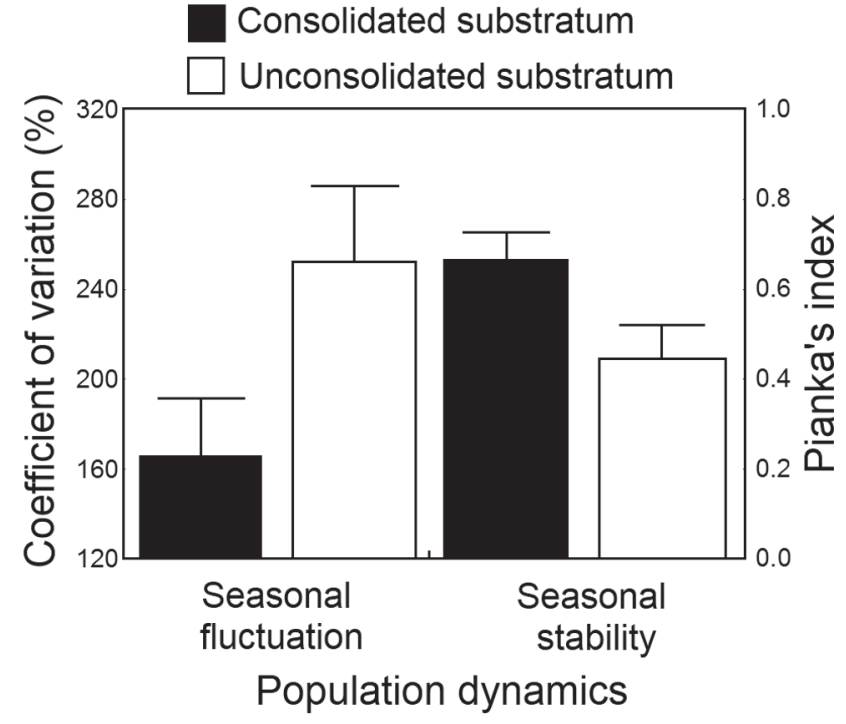

Fig. 2. Mean values ( \pm SE) of temporal fluctuation and temporal stability.

a response to microhabitat characteristics, since these latter showed small temporal fluctuations. This supposition is corroborated by the fact that juveniles were approximately seven times more abundant in May than in October, indicating the potential role of recruitment in temporal variation. Although adults were more abundant in May, the magnitude of such temporal difference was smaller than that recorded for juveniles. May was an important recruitment month for $A$. chirurgus, H. chrysargyreum, S. amplum, S. frondosum, $S$. rocasensis, and T. noronhanum in the study area. Although temporal variations in the abundance of juveniles were not related to microhabitat characteristics, other factors such as hydrodynamics and primary productivity, which are potentially determinants of reef fish recruitment (Russel et al., 1977; McGehee, 1994; Bellwood et al., 2002; Wainwright et al., 2002; Floeter et al., 2007), were not evaluated here.

The two indexes of temporal dynamics (fluctuation and stability) (Nanami \& Nishihira, 2003) strongly distinguished between fish assemblages at the CS and US stations. It is likely that the higher availability of shelter and food at CS stations may reduce competition and predation, therefore decreasing temporal fluctuations. Although other factors may influence the structure of fish assemblages (e.g. stochastic recruitment; Sale, 1978, 1980), it is well known that refuge availability decreases the rates of encounter between predators and their prey and amongst competing individuals (e.g. Victor, 1983; Beukers \& Jones, 1997). It is suggested here that these processes are most likely to operate at the US stations, thus increasing temporal variability.

\section{Effects of habitat complexity}

As expected, structural complexity was higher at CS stations. Hard substratum tend to show high structural heterogeneity and provide appropriate settlement sites for 


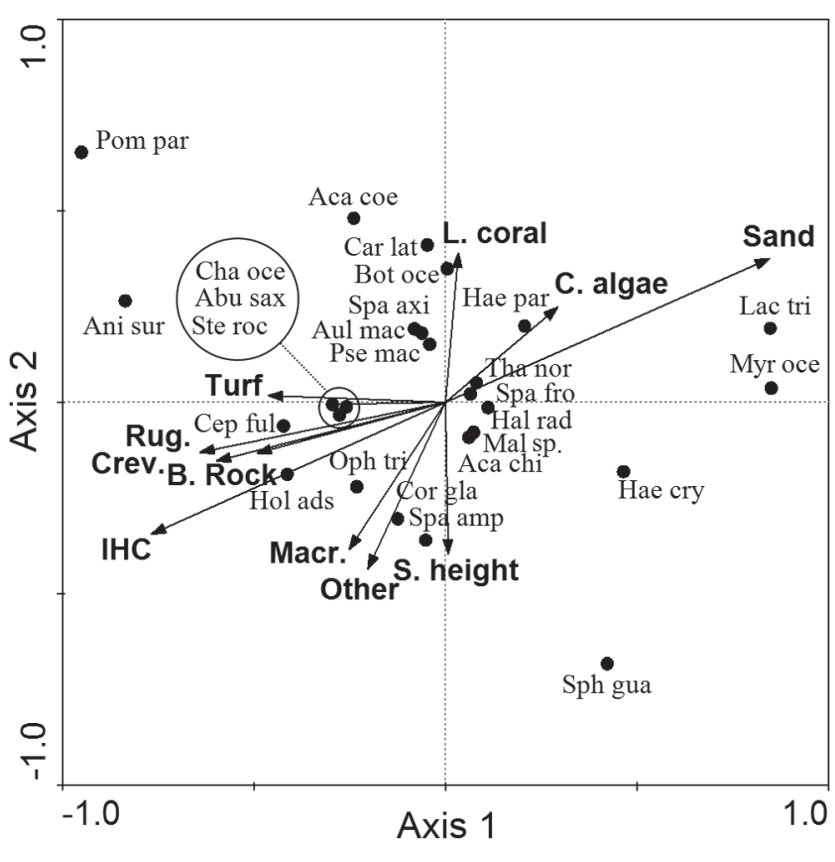

Fig. 3. Canonical plotting of microhabitat characteristics (arrows) and fish species (points). Rug.: rugosity; Crev.: number of crevices; S. height: substratum height; $\mathrm{C}$. algae: percent cover of encrusting coralline algae; Macr.: percent cover of Macroalgae; Turf: percent cover of turf algae; L. coral: percent cover of live coral; Other: percent cover of other organisms; B. rock: percent cover of bare rock; Sand: percent cover of sand and limestone; IHC: index of habitat complexity; Species names are abbreviated as the first three letters of genus and first three letters of specific epithet (see Table 4 for full scientific names).

sessile organisms such as corals and algae (Schuhmacher, 1988; Abelson et al., 1993), therefore, increasing the availability of shelter (Hixon \& Beets, 1989; Borntrager \& Farrell, 1992; Eggleston et al., 1992) and food (Fitzhardinge \& Bailey-Brock, 1989; Ch'ng \& Thomas, 1991). The unconsolidated substrate, on the other hand, has obvious limitations regarding both availability of shelter and food, therefore limiting niche diversification. In this study, $48 \%$ and $85 \%$ of the surface areas of the US and CS stations were colonized by live benthic organisms, respectively.

As mentioned previously, the factors that significantly influenced species richness had no influence on fish abundance (e.g. topographic complexity). Although this pattern had been previously acknowledged by other authors, a satisfying explanation to it is not yet available (e.g. Sale \& Dybdahl, 1975; Carpenter et al., 1981; McManus et al., 1981; Roberts \& Ormond, 1987; Almany, 2004). Nonetheless, it becomes increasingly clear that reef fish species richness and abundance are usually regulated by different factors. Based on our results and those from previous studies (e.g. Carpenter et al., 1981; Roberts \& Ormond, 1987; McCormick, 1994; Chabanet et al., 1997; Medeiros et al., 2010b), one
Table 6. Pearson's correlation results ( $r$ and $p$ values) on the relationship between fish and crevice sizes. *: significant ( $p$ $>0.05)$; **: highly significant $(\mathrm{p}<0.001)$; ns: non-significant $(\mathrm{p}>0.05)$

\begin{tabular}{lcccc}
\hline Fish size & \multicolumn{4}{c}{ Crevice size } \\
& $1-5 \mathrm{~cm}$ & $5-10 \mathrm{~cm}$ & $10-20 \mathrm{~cm}$ & $>20 \mathrm{~cm}$ \\
\hline $1-5 \mathrm{~cm}$ & $0.20(n s)$ & $0.24(n s)$ & $0.12(n s)$ & $0.22(n s)$ \\
$5-10 \mathrm{~cm}$ & $0.46(* *)$ & $0.22(n s)$ & $0.15(n s)$ & $0.09(n s)$ \\
$10-15 \mathrm{~cm}$ & $0.33(* *)$ & $0.24(n s)$ & $0.32(*)$ & $0.41(* *)$ \\
$15-20 \mathrm{~cm}$ & $0.24(n s)$ & $0.22(n s)$ & $0.36\left(^{* *}\right)$ & $0.38(* *)$ \\
$20-25 \mathrm{~cm}$ & $-0.01(n s)$ & $0.12(n s)$ & $0.27(*)$ & $0.24(n s)$ \\
$25-30 \mathrm{~cm}$ & $0.13(n s)$ & $-0.11(n s)$ & $-0.03(n s)$ & $0.11(n s)$ \\
$>30 \mathrm{~cm}$ & $0.19(n s)$ & $0.10(n s)$ & $0.24(n s)$ & $0.29(*)$ \\
\hline
\end{tabular}

emergent hypothesis is that the nature of the substratum is vital for species richness, whereas resource availability (i.e. food) is most likely to determine fish abundance. In this scenario, a diverse and physically complex location may harbor several species with different substratum preferences, thus increasing species richness, but not necessarily enhance fish abundance. On the other hand, a location dominated by one single substratum component (e.g. turf algae) may attract several individuals of one or few species that use this component as food. Future experimental studies investigating these questions are encouraged.

Live coral cover, an important predictor of reef fish species richness and abundance (Bell \& Galzin, 1984; Bouchon-Navaro \& Bouchon, 1989; Chabanet et al., 1997), had no influence on species richness and fish abundance in the present study. The positive relationship between coral cover and reef fish abundance/species richness is more pronounced for some particular taxa (e.g. some chaetodontids which feed directly on coral polyps), but may be weak or even negative for other groups (e.g. herbivorous fish) (Wilson et al., 2006). Aside from feeding resources, branching corals provide important refuge for small fish (Bellwood et al., 2004). Therefore, the weak relationship between coral cover and species richness/fish abundance in the present study possibly resulted from three factors: low abundances of coralivorous fish, low coral diversity and, most importantly, the low variety of coral morphotypes, with massive forms dominating. The low profile of Brazilian corals (Maida \& Ferreira, 1997) preclude most fishes from using them as refuge sites, unlike those of the Caribbean and IndoPacific, which show high species and morphological diversity, with vertical branches serving as shelter for small fish.

Macroalgae were an important determinant of fish distribution in the present study. These algae are very common in the tropical reefs of the Southwestern Atlantic (Medeiros et al., 2010b), but their importance has been reasonably understudied and somewhat obscured in fish-habitat association studies. At Porto beach, macroalgae provide feeding resources for many herbivorous and omnivorous fishes and refuge for small invertebrates and sedentary fishes, thus functioning in a similar way as seagrass beds (Nakamura $\&$ Sano, 2004). These authors, for example, concluded that leaf height of two seagrass species were positive determinants 
Table 7. Results of ANCOVAs testing the influence of substratum type on fish richness and abundance using the IHC as a covariate. $n s$ : non-significant

\begin{tabular}{llcccc}
\hline & Effect & df & MS & F & p \\
\hline Richness & Substratum & 1 & 39.76 & 7.77 & $<0.01$ \\
& IHC & 1 & 48.78 & 9.53 & $<0.01$ \\
& Residual & 57 & 5.12 & & \\
\hline Abundance & Substratum & 1 & 827.3 & 0.54 & $n s$ \\
& IHC & 1 & 2355.8 & 1.55 & $n s$ \\
& Residual & 57 & 1517.42 & & \\
\hline
\end{tabular}

of fish species richness and abundance, for providing feeding resources and refuge sites. The importance of vertical structures as determinants of fish distribution was also acknowledged by several authors (Carpenter et al., 1981; Bell \& Galzin, 1984; Munday et al., 1997; Bergman et al., 2000; Horinouchi \& Sano, 2001), but the specific effects of macroalgae are poorly documented (but see Carr, 1994).

Our results indicated that in a small spatial-scale fishes were non-randomly distributed along a continuum of rocky and unconsolidated habitats, due mainly to variations in substratum characteristics and the inherent features of fishes (i.e. habitat preferences), but not to geographical barriers restraining fish movement. CS stations housed a higher number of species than unconsolidated ones, but fish density was not significantly influenced by substratum type, this same result being obtained in two seasons. Also, the relative contribution of each particular microhabitat variable evaluated to reef fish differed significantly. For example, topographical complexity and percent algal cover (except coralline algae) were amongst the most important determinants of fish species richness, and clear correlations between fish size and refuge crevice sizes were observed. On the other hand, the less complex profile and low availability of algae were limiting factors to species richness at the US stations. These results highlight the importance of assessing several microhabitat variables concomitantly in order to adequately determine their relative influence in the structure of reef fish assemblages.

\section{Acknowledgements}

We are indebted to Ana Maria Alves de Medeiros and Renato Grotta Grempel, for assistance during field work, Miriam Barbosa and the overall staff of Instituto Chico Mendes de Conservação da Biodiversidade (ICMBio), for providing logistic support and accommodation in the island, and Conselho Nacional de Desenvolvimento Científico e Tecnológico $(\mathrm{CNPq})$, for providing financial support.

\section{Literature Cited}

Abelson, A., T. Miloh \& Y. Loya. 1993. Flow patterns induced by substrata and body morphologies of benthic organisms and their roles in determining availability of food particles. Limnology and Oceanography, 38: 1116-1124.
Almany, G. R. 2004. Differential effects of habitat complexity, predators and competitors on abundance of juveniles and adult coral reef fishes. Oecologia, 141: 105-113.

Ault, T. R. \& C. R. Johnson. 1998. Spatially and temporally predictable fish communities on coral reefs. Ecological Monographs, 68: 25-50.

Bell, J. D. \& R. Galzin. 1984. Influence of live coral cover on coral reef fish communities. Marine Ecology Progress Series, 15: 265-274.

Bellwood, D. R, T. P. Hughes, C. Folke \& M. Nyström. 2004. Confronting the coral reef crisis. Nature, 429: 827-833.

Bellwoood, D. R. \& P. C. Wainwright. 2002. The history and biogeography of fishes on coral reefs. Pp. 5-32. In: Sale, P. F. (Ed.). Coral reef fishes: dynamics and diversity in a complex ecosystem. San Diego, Academic Press, 549p.

Bellwood, D. R., P. C. Wainwright, C. J. Fulton \& A. Hoey. 2002. Assembly rules and functional groups at global biogeographical scales. Functional Ecology, 6: 557-562.

Bergman, K. C., M. C. Öhman \& S. Svensson. 2000. Influence of habitat structure on Pomacentrus sulfurous, a western Indian Ocean reef fish. Environmental Biology of Fishes, 59: 243-252.

Beukers, J. S. \& G. P. Jones. 1997. Habitat complexity modifies the impact of piscivores on a coral reef fish population. Oecologia, 114: 50-59.

Borntrager, J. F. \& T. M. Farrell. 1992. The effect of artificial reef size on species richness and diversity in a Florida estuary. Florida Scientist, 55: 229-235.

Bouchon-Navaro, Y. \& C. Bouchon. 1989. Correlations between chaetodontid fishes and coral communities of the Gulf of Aqaba (Red Sea). Environmental Biology of Fishes, 25: 47-60.

Campos, C. E. C., M. B. Silva, S. G. Targino, J. C. Sá-Oliveira \& A. S. Araújo. 2006. Simbiose de limpeza de Thalassoma noronhanum (Boulenger, 1890) (Labridae) na reserva biológica do Atol das Rocas, Rio Grande do Norte, Brasil. Revista de Etologia, 8: 63-70.

Carpenter, K. E., R. I. Miclat, V. D. Albaladejo \& V. T. Corpuz. 1981. The influence of substrate structure on the local abundance and diversity of Philippine Reef Fishes. Proceedings of the $4^{\text {th }}$ International Coral Reef Symposium, 497-502.

Carr, M. H. 1994. Effects of macroalgal dynamics on recruitment of a temperate reef fish. Ecology, 75: 1320-1333.

Castro, C. B. 2003. Coral reef in Brazil. Pp. 25-27. In: Prates, A. P. L. (Ed.). Atlas of Coral Reef Protected Areas in Brazil. Brasília, MMA/SBF.

Ch'ng, K. L. \& C. Thomas. 1991. An artificial reef program in Malaysia. Pp. 305-309. In: Chou, L. M., T. E. Chua, H. W. Khoo, P. E. Li, J. N. Paw, G. T. Silvestre, M. J. Valencia, A. T. White \& P. K. Wong (Eds.). Towards an integrated management of tropical coastal resources. Singapore, ICLARM Conference Proceedings, 455p.

Chabanet, P., H. Ralambondrainy, M. Amanieu, G. Faure \& R. Galzin. 1997. Relationship between coral reef substrata and fish. Coral Reefs, 16: 93-102.

Charbonnel, E., C. Serre, S. Ruitton, J. Harmelin \& A. Jensen. 2002. Effects of increased habitat complexity on fish assemblages associated with large artificial reef units (French Mediterranean coast). ICES Journal of Marine Science, 59: 208-213.

Choat, J. H. \& D. R. Bellwood. 1991. Reef fishes: their history and evolution. Pp. 39-66. In: Sale, P. F. (Ed.). The Ecology of Fishes on Coral Reefs. San Diego, Academic Press, 549p.

Costa Jr., O. S., M. J. Attrill, A. G. Pedrini \& J. C. De-Paula. 2001. Benthic macroalgal distribution in coastal and offshore reefs at Porto Seguro Bay, Brazilian Discovery Coast. Proceedings of the $9^{\text {th }}$ International Coral Reef Symposium, 499-508. 
Denny, M. W. 1994. Roles of hydrodynamics in the study of life on wave-swept shores. Pp. 169-204. In: Wainwright, P. C. \& S. M. Reilly (Eds.). Ecological morphology: integrative organismal biology. Chicago, University of Chicago Press, 376p.

Eggleston, D. B., R. N. Lipcius \& D. L. Miller. 1992. Artificial shelters and survival of Caribbean spiny lobster Panulirus argus: spatial, habitat and lobster size effects. Fisheries Bulletin, 90: 691-702.

Ferreira, C. E. L., J. E. A. Goncalves, \& R. Coutinho. 2001. Community structure of fishes and habitat complexity on a tropical rocky shore. Environmental Biology of Fishes, 61: 353-369.

Fitzhardinge, R. C. \& J. H. Bailey-Brock. 1989. Colonization of artificial reef materials by corals and other sessile organisms. Bulletin of Marine Science, 44: 567-579.

Floeter, S. R. \& J. L. Gasparini. 2000. The southwestern Atlantic reef fish fauna: composition and zoogeographic patterns. Journal of Fish Biology, 56: 1099-1114.

Floeter, S. R., W. Krohling, J. L. Gasparini, C. E. L. Ferreira \& I. R. Zalmon. 2007. Reef fish community structure on coastal islands of the southeastern Brazil: the influence of exposure and benthic cover. Environmental Biology of Fishes, 78: 147-160.

Francini-Filho, R. B., R. L. Moura \& I. Sazima. 2000. Cleaning by the wrasse Thalassoma noronhanum, with two records of predation by its grouper client Cephalopholis fulva. Journal of Fish Biology, 56: 802-809.

Gotelli, N. J. \& G. R. Graves. 1996. Null models in ecology. Washington, Smithsonian Institution Press, 368p.

Gratwicke, B. \& M. R. Speight. 2005. The relationship between fish species richness, abundance and habitat complexity in a range of shallow tropical marine habitats. Journal of Fish Biology, 66: 650-667.

Gust, N., J. H. Choat \& M. I. McCormick. 2001. Spatial variability in reef fish distribution, abundance, size and biomass: a multiscale analysis. Marine Ecology Progress Series, 214: 237-251.

Hixon, M. A. 1991. Predation as a process structuring coral reef fish communities. Pp. 475-508. In: Sale, P. F. (Ed.). The ecology of fishes on coral reefs. San Diego, Academic Press, 549p.

Hixon, M. A. \& J. P. Beets. 1989. Shelter characteristics and Caribbean fish assemblages: experiments with artificial reefs. Bulletin of Marine Science, 44: 666-680.

Horinouchi, M. \& M. Sano. 2001. Effects of changes in seagrass shoot density and leaf height on the abundance of juveniles of Acentrogobius pflaumii in a Zostera marina bed. Ichthyological Research, 48: 179-185.

Humann, P. \& N. DeLoach. 2002. Reef fish identification: Florida, Caribbean, Bahamas. Miami, New World Publications, 359p.

Lefèvre, C. D. \& D. R. Bellwood. 2010. Seasonality and dynamics in coral reef macroalgae: variation in condition and susceptibility to herbivory. Marine Biology, 157: 955-965.

Lieske, E. \& R. Myers. 2001. Collins Pocket Guide: Coral Reef Fishes. London, Collins, 420p.

Luckhurst, B. E. \& K. Luckhurst. 1978. Analysis of the influence of substrate variables on coral reef fish communities. Marine Biology, 49: 317-323.

Maida, M. \& B. P. Ferreira. 1997. Coral reefs of Brazil: an overview. Proceedings of the $8^{\text {th }}$ International Coral Reef Symposium, 263-274.

McCormick, M. I. 1994. Comparison of field methods for measuring surface topography and their associations with a tropical reef fish assemblage. Marine Ecology Progress Series, 112: 87-96.

McGehee, M. A. 1994. Correspondence between assemblages of coral reef fishes and gradients of water motion, depth and substrate size off Puerto Rico. Marine Ecology Progress Series, 105: 243-255.

McManus, J., R. Miclat \& V. Palaganas. 1981. Coral and fish community structure of Sombrero Island at Batangas, Philippines. Proceedings of the $4^{\text {th }}$ International Coral Reef Symposium, 271-280.

Medeiros, P. R., R. G. Grempel, A. T. Souza, M. I. Ilarri \& R. S. Rosa. 2010b. Non-random reef use by fishes on two dominant zones in a tropical, algal-dominated coastal reef. Environmental Biology of Fishes, 87: 237-246.

Medeiros, P. R., A. T. Souza \& M. I. Ilarri. 2010a. Habitat use and behavioural ecology of the juveniles of two sympatric damselfishes (Actinopterygii: Pomacentridae) in the southwestern Atlantic Ocean. Journal of Fish Biology, 1-17.

Mellin, C., J. Ferraris, R. Galzin, M. Kulbicki \& D. Ponton. 2006. Diversity of coral reef fish assemblages: modelling of the species richness spectra from multi-scale environmental variables in the Tuamoto Archipelago (French Polynesia). Ecological Modelling, 198: 409-425.

Minte-Vera, C. V., R. L. Moura \& R. B. Francini-Filho. 2008. Nested sampling: an improved visual-census technique for studying reef fish assemblages. Marine Ecology Progress Series, 367: 283-293.

Munday, P. L., G. P. Jones \& M. J. Caley. 1997. Habitat specialization and the distribution and abundance of coraldwelling gobies. Marine Ecology Progress Series, 152: 227239.

Nakamura, Y. \& M. Sano. 2004. Overlaps in habitat use of fishes between a Seagrass bed and adjacent coral and sand areas at Amitori Bay, Iriomote Island,Japan: Importance of the Seagrass bed as juvenile habitat. Fisheries Science, 70: 788-803.

Nanami, A. \& M. Nishihira. 2003. Population dynamics and spatial distribution of coral reef fishes: comparison between continuous and isolated habitats. Environmental Biology of Fishes, 68: 101-112.

Ohman, M. C. \& A. Rajasuriya. 1998. Relationships between habitat structure and fish communities on coral and sandstone reefs. Environmental Biology of Fishes, 53: 19-31.

Ornellas, A. \& R. Coutinho. 1998. Spatial and temporal patterns of distribution and abundance of a tropical fish assemblage in a seasonal Sargassum bed, Cabo Frio Island, Brazil. Journal of Fish Biology, 53: 198-208.

Pianka, E. R. 1973. The structure of lizard communities. Annual Review of Ecology and Systematics, 4: 53-74.

Porter, J. W. 1972. Patterns of species diversity in Caribbean reef corals. Ecology, 53: 745-748.

Randall, J. E. 1967. Food habits of reef fishes of the West Indies. Studies in Tropical Oceanography, 5: 665-847.

Roberts, C. M. \& R. F. G. Ormond. 1987. Habitat complexity and coral reef fish diversity and abundance on Red Sea fringing reefs. Marine Ecology Progress Series, 41: 1-8.

Rogers, C. S., G. Garrison, R. Grobber, Z. Hillis \& M. A. Franke. 1994. Coral Reef Monitoring Manual for the Caribbean and Western Atlantic. St. John, Virgin Islands National Park, 110p.

Russel, B. C., G. R. V. Anderson \& F. H. Talbot. 1977. Seasonality and recruitment of coral reef fishes. Australian Journal of Marine and Freshwater Research, 28: 521-528.

Russel, B. C., F. H. Talbot \& S. Domm. 1974. Patterns of colonization of artificial reefs by coral reef fishes. Proceedings of the $2^{\text {nd }}$ International Coral Reef Symposium, 207-215.

Sale, P. F. 1977. Maintenance of high diversity in coral reef fish communities. American Naturalist, 111: 337-359. 
Sale, P. F. 1978. Coexistence of coral reef fishes - a lottery for living space. Environmental Biology of Fishes, 3: 85-102.

Sale, P. F. 1980. Assemblages of fishes on patch reefs - predictable of unpredictable? Environmental Biology of Fishes, 5: 243-249.

Sale, P. F. 2004. Connectivity, recruitment variation and the structure of reef fish communities. Integrative and Comparative Biology, 44: 390-399.

Sale, P. F. \& R. Dybdahl. 1975. Determinants of community structure for coral reef fishes in an experimental habitat. Ecology, 56: 1343-1355.

Schuhmacher, H. 1988. Development of coral communities on artificial reef types over twenty years (Eliat, Red Sea). Proceedings of the $6^{\text {th }}$ International Coral Reef Symposium, 379-384.

Talbot, F. H., B. C. Russell \& G. R. V. Anderson. 1978. Coral reef fish communities: unstable, high diversity systems? Ecological Monographs, 48: 425-440.

ter Braak, C. J. F. 1986. Canonical Correspondence Analysis: A new eigenvector technique for multivariate direct gradient analysis. Ecology, 67: 1167-1179.

ter Braak, C. J. F. \& P. F. M. Verdonschot. 1995. Canonical correspondence analysis and related multivariate methods in aquatic ecology. Aquatic Sciences, 57: 255-289.

Victor, B. C. 1983. Recruitment and population dynamics of a coral reef fish. Science, 219: 419-420.

Wainwright, P. C., D. R. Bellwood \& M. W. Westneat. 2002. Ecomorphology of locomotion in labrid fishes. Environmental Biology of Fishes, 65: 47-62.

Wellington, G. M. \& B. C. Victor. 1985. El Nino mass coral mortality: a test of resource limitation in a coral reef damselfish population. Oecologia, 68: 15-19.

Wilkinson, L., G. Blank \& C. Gruber. 1996. Desktop data analysis with SYSTAT. Englewood Cliffs, Prentice Hall, 848p.

Wilson, S. K., N. A. J. Graham, M. S. Pratchett, G. P. Jones \& N. V. C. Polunin. 2006. Multiple disturbances and the global degradation of coral reefs: are reef fishes at risk or resilient? Global Change Biology, 12: 2220-2234.

Submitted October 20, 2010

Accepted October 13, 2011

Published December 26, 2011 